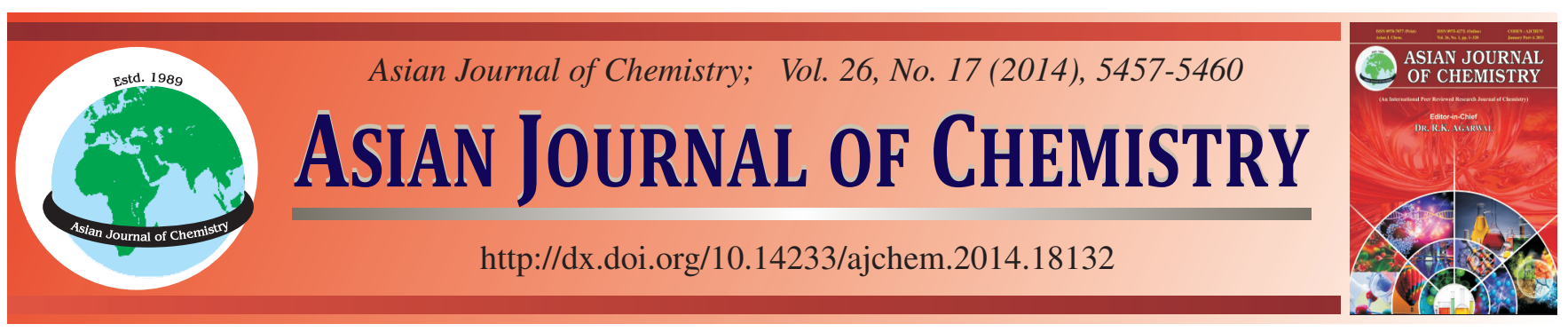

\title{
Soil C, N and P Stoichiometry of Shrub Communities in Chenier Wetlands in Yellow River Delta, China $\dagger$
}

\author{
Y.Y. ZHAO ${ }^{1,2}$, X.M. Hü ${ }^{2}$ and Z.H. Lu ${ }^{1, *}$
}

${ }^{1}$ Institute of Restoration Ecology, School of Chemical \& Environmental Engineering, China University of Mining \& Technology, Beijing, P.R. China ${ }^{2}$ Shandong Provincial Key Laboratory of Eco-Environmental Science for Yellow River Delta, Binzhou University, Binzhou, P.R. China

*Corresponding author: Tel./Fax: +86 543 3195580; E-mail: xiangming0727@163.com

\begin{abstract}
The stoichiometry of C, N, P has improved understanding of nutrient circulation in ecosystems. However, little information is available about coastal wetlands. Here, wetland soil ecological stoichiometric features of carbon, nitrogen and phosphorus in two different shrub communities (Tamarix chinensis and Ziziphus jujube) in chenier of Yellow river delta were studied. The results showed that there was little soil total organic carbon content with large variation. The content of total nitrogen and phosphorus were extremely lacked, which might be two important nutrient limiting factors for these two plant communities. Soil $\mathrm{R}_{\mathrm{CN}}$ was much higher than regional and global scales, however, $R_{C P}$ and $R_{N P}$ were far below those two scales. The variation of $R_{C N}, R_{C P}$ and $R_{N P}$ were $1.86,67.62$ and $106.32 \%$, which characterized relatively stable $\mathrm{R}_{\mathrm{CN}}$ in $0-30 \mathrm{~cm}$ soil in this region. By multiple linear regression analysis, the vegetation community type and soil moisture were key factors affecting soil stoichiometric features.
\end{abstract}

Keywords: Soil stoichiometry, Yellow river delta, Chenier, Wetlands.

\section{INTRODUCTION}

The chemical composition of elements in the environment influences the relative elementary composition of organisms and vice versa, due to the absorption, utilization and release of elements by organisms, element content and body ratio also reflects the state and amount of elements in the environment ${ }^{1}$. Through the course of interactions between organisms and their environments, the regional element cycle tends to be stabilized and the ratios of chemical elements also tend to be balanced, both in the environment and within organisms. These dynamics enable stoichiometry to be utilized for studying the coupling relations among various environmental processes ${ }^{2}$. On earth, carbon, nitrogen and phosphorus form the basis of the chemical composition of all life forms; as such they are the major elements studied in stoichiometry and their ratios are inextricably linked to the function of ecosystem ${ }^{3}$.

Many previous studies have indicated that, at a large scale, the $\mathrm{C}$ : $\mathrm{N}$ : P molar ratio $\left(\mathrm{R}_{\mathrm{CNP}}\right)$ of living tissues is constant. For example, in marine, $\mathrm{R}_{\mathrm{CNP}}$ is $106: 16: 1$ for plankton, 307:30:1 for plants and 124:22:1 for arthropods. In terrestrial ecosystems the mean $\mathrm{R}_{\mathrm{CNP}}$ is $968: 28: 1$ for plants ${ }^{1,4}$. $\mathrm{N}$ and $\mathrm{P}$ are two important elements necessary for plant growth and the leaf $\mathrm{N}$ : P ratio $\left(\mathrm{R}_{\mathrm{NP}}\right)$ is commonly employed as a criterion to determine whether ecosystems or species are restricted by low $\mathrm{N}$ or $\mathrm{P}$ availability ${ }^{3}$. Such studies are highly instructive for identifying factors that restrict the growth, organism's evolution and more broadly, for revealing the impact of the biogeochemical cycle in various ecosystems. Thus, stoichiometry analyses of terrestrial and aquatic ecosystems have become an essential component of biological research. However, as of now, the burgeoning chemometric literature concentrates mainly on well-studied species and their communities, less attention has been paid to soil $\mathrm{R}_{\mathrm{CNP}}^{5,6}$.

Carbon, nitrogen and phosphorus content in the soil constitute not only a key and essential raw material for plants survival, but also an important determinant of both the primary productivity and biogeochemical cycle of the earth. The content of these three factors and their relative balance are closely related to the nutrient content and stoichiometric characteristics of plants and thus affect the plant growth, community species composition and productivity ${ }^{7,8}$. Coastal wetlands were transitional region between sea and land with harsh conditions. The size of soil carbon pools and proportion relationship with $\mathrm{N}$ and $\mathrm{P}$ elements, not only embody the wetland soil carbon consumptive and storage capacity, but also reflect the maintenance 
mechanism of primary productivity in ecotone ecosystem ${ }^{5,9-11}$. However, up to now, stoichiometric studies of wetland soils are rare. Here, by using Chenier wetlands in Yellow river delta as study area, the research objectives were: (1) to study the soil $\mathrm{R}_{\mathrm{CNP}}$ characteristics of chenier wetland ecosystem; (2) to examine the factors influencing soil stoichiometric characteristics. Further, a comparison of soil stoichiometric characteristics at global, country and local scale was conducted, to verify whether a similarly stable $\mathrm{R}_{\mathrm{CNP}}$ ratio existence in chenier wetland soils.

\section{EXPERIMENTAL}

Study area: The study was conducted within the national nature reserve, in the chenier wetland ecosystem of the Yellow river delta, Wudi County, Shandong Province, China. The city lies in the East Asia Monsoon Continental Sub-humid Climate Zone, within the Warm Temperate Zone (N37º502 -38²02, E117 $502-118^{\circ} 102$ ). It is characterized by a mild climate, four distinct seasons with obvious wet and dry seasons, a mean temperature of $13.6{ }^{\circ} \mathrm{C}$ and annual precipitation of 500-900 $\mathrm{mm}$. The wide spatial distribution of mudflats and marshes is an important characteristic of this coastal wetland. Its soil matrix is constituted of shell, sand and mud, with a unit weight of $1.2 \mathrm{~g} / \mathrm{cm}^{3}$, with a coarse particle diameter, large porosity, weak water and fertilizer retention and large daily temperature differences, with rapid rises in the daytime and rapid declines at night. The plants at the site are mainly perennial herbs with many modes of reproduction. Tamarix chinensis and Ziziphus jujube are two dominant shrubs that are relatively well-distributed. (1) T. chinensis is located near the high-water line on the seaward side of the ridge; due to the low ground-water level it is frequently accompanied by saline-alkaline tolerant plants such as Zoysia macrostachya, Messerschmidia sibirica L., Limonium bicolor and Scorzonera mongolica, along with water-tolerant plants such as Phragmites australis. It tends to grow in colonies, with a low vegetation coverage (mean $42 \%$ ); bare soil is seen frequently in this environment and below the shrub there is very little or no layer of humus. (2) Ziziphus jujube is located on fixed/semi-fixed embankments on top of or behind the dune of the chenier. It coexists with Artemisia mongolica in most cases, with a high vegetation coverage (mean $>80 \%$ ) and a humus layer thickness of 0-1.0 cm (Table-1).

Sample collection: In mid-July 2013, 15 locations were chosen for soil sampling in Tamarix Chinensis and Ziziphus jujube communities (three to five years old and 1.22-1.95 m height, Table-1). In tree stem base, under canopy and crown outside, $0-30 \mathrm{~cm}$ soil cores with $5 \mathrm{~cm}$ increments were conducted. The sampled soil in same soil layer of each tree was mixed evenly, put into a plastic bag, sealed and brought to the lab for assessment. 180 soil samples were obtained.

Chemical analysis: In our laboratory the soils were screened immediately through $2 \mathrm{~mm}$ sieve. The part of the soil was measured, baked in a drying oven for at least $24 \mathrm{~h}$ at $105{ }^{\circ} \mathrm{C}$ and its mass of water content was then determined. The remainder of each soil sample was air dried for $15 \mathrm{~d}$. A part of that dried soil was used to determine the content of total organic carbon (TOC), total nitrogen (TN) and total phosphorus (TP). $\mathrm{K}_{2} \mathrm{Cr}_{2} \mathrm{O}_{7}-\mathrm{H}_{2} \mathrm{SO}_{4}$ oxidation process is used to determine total organic carbon content, a flow injection analyzer (AA3) to determine total nitrogen content after heat digestion with $\mathrm{H}_{2} \mathrm{SO}_{4}-\mathrm{HClO}_{4}$ and the Mo-Sb colorimetric method to determine total phosphorus contents after heat digestion with $\mathrm{H}_{2} \mathrm{SO}_{4}-\mathrm{HClO}_{4}$.

Statistical analysis: The molar mass contents of $\mathrm{C}, \mathrm{N}$ and $\mathrm{P}$ per unit mass $(\mathrm{mol} / \mathrm{kg}$ ) were obtained by dividing the measured mass content of each element $(\mathrm{g} / \mathrm{kg})$ by its atomic weight. The $C: N, C: P$ and $N: P$ ratios $\left(R_{C N}, R_{C P}\right.$ and $\left.R_{N P}\right)$ were calculated from the molar mass contents of each soil sample ${ }^{12}$. The mean content of total organic carbon, total nitrogen and total phosphorus of all samples was used as the pattern of shrub communities' soil nutrient. In order to compare the variance between Tamarix chinensis and Ziziphus jujube community, the mean nutrient content and molar ratios of elements from the $0-30 \mathrm{~cm}$ soil layer in each of the two communities were determined and these measures were used in a difference test $(p<0.05)$. A multivariate regression analysis was conducted between community's type, soil depth, soil water content, groundwater level and the total organic carbon, total nitrogen, total phosphorus content, $\mathrm{C}: \mathrm{N}, \mathrm{C}: \mathrm{P}$ and $\mathrm{N}: \mathrm{P}$ ratios at an alpha level of 0.05. Analyses were conducted using the Excel 2003 and SPSS11.0 software.

\section{RESULTS AND DISCUSSION}

Soil C, $\mathbf{N}$ and $\mathrm{P}$ stoichiometry of shrub communities in chenier wetlands: Soil C, N and P in $0-30 \mathrm{~cm}$ soil depth averaged $3.73,0.11$ and $0.14 \mathrm{~g} / \mathrm{kg}$ in chenier shrub communities and the coefficient of variation was $100.80,90.91$ and $50 \%$, respectively (Table-2). $\mathrm{R}_{\mathrm{CNP}}$ was 66.73:1.69:1, while $\mathrm{R}_{\mathrm{CN}}, \mathrm{R}_{\mathrm{CP}}$ and $\mathrm{R}_{\mathrm{NP}}$ were 53.73, 62.39 and 2.60 with $1.86,67.62$ and $106.32 \%$ variance, respectively.

Factors analysis of soil C, N, P stoichiometry: A multivariate regression analysis showed that vegetation type and soil water content were two important factors that influenced the content total organic carbon, total nitrogen and total phosphorus of chenier soils, in addition to the community type to $\mathrm{R}_{\mathrm{CN}}$ and soil moisture to $\mathrm{R}_{\mathrm{NP}}$ (Table-3). However, soil depth and groundwater level had no influence on the $\mathrm{C}, \mathrm{N}$ and $\mathrm{P}$ stoichiometry.

The coastal wetland ecosystem is the area that experiences the most intensive biogeochemical cycling at the marineterrestrial interface. Being a vulnerable ecological belt, it has always been a hot spot for wetland researchers ${ }^{5,10,11}$. The chenier wetland of Yellow river delta is a beach ridge or dune-shaped coastal wetland, most of which are a large amount number of

TABLE-1

SUMMARY OF COMMUNITY IN CHENIER OF YELLOW RIVER DELTA

\begin{tabular}{lcccl}
\hline \multicolumn{1}{c}{ Community } & Groundwater level $(\mathrm{m})$ & Tree age (a) & Tree height $(\mathrm{m})$ & \multicolumn{1}{c}{ Associated species } \\
\hline T. chinensis & $0.5-0.7$ & $3-5$ & $1.22-1.63$ & $\begin{array}{l}\text { Zoysia macrostachya, Messerschmidia sibirica, Limonium } \\
\text { bicolor, Scorzonera mongolica, Phragmites australis }\end{array}$ \\
Z. jujube & $0.75-1.5$ & $4-5$ & $1.25-1.95$ & Artemisia mongolica, Metaplexis japonica, Aster tataricus \\
\hline
\end{tabular}




\begin{tabular}{|c|c|c|c|c|}
\hline Community & TOC & \multicolumn{2}{|c|}{$\mathrm{TN}$} & TP \\
\hline T. chinensis & $1.49 \pm 0.79^{*}$ & \multicolumn{2}{|c|}{$0.04 \pm 0.02 *$} & $0.11 \pm 0.04$ \\
\hline Z. jujube & $6.03 \pm 4.19$ & \multicolumn{2}{|c|}{$0.18 \pm 0.10$} & $0.18 \pm 0.08$ \\
\hline Average & $3.73 \pm 3.76$ & \multicolumn{2}{|c|}{$0.11 \pm 0.10$} & $0.14 \pm 0.07$ \\
\hline \multicolumn{5}{|c|}{$\mathrm{TOC}=$ Total organic carbon $; \mathrm{TN}=$ Total nitrogen $; \mathrm{TP}=$ Total phosph } \\
\hline \multicolumn{5}{|c|}{$\begin{array}{c}\text { TABLE-3 } \\
\text { EFFECTING FACTORS ANALYSIS OF SOIL } \mathrm{R}_{\mathrm{CN}}, \mathrm{R}_{\mathrm{CP}} \\
{\text { AND R } \mathrm{R}_{\mathrm{NP}} \text { IN CHENIER IN YELLOW RIVER DELTA }}\end{array}$} \\
\hline \multirow[b]{2}{*}{ Indicators } & \multicolumn{4}{|c|}{ Significance $\mathrm{P}$} \\
\hline & $\begin{array}{c}\text { Groundwater } \\
\text { level }\end{array}$ & Community & $\begin{array}{c}\text { Water } \\
\text { content }\end{array}$ & $\begin{array}{c}\text { Soil } \\
\text { depth }\end{array}$ \\
\hline TOC & 0.108 & 0.000 & 0.000 & 0.008 \\
\hline $\mathrm{TN}$ & 0.127 & 0.000 & 0.000 & 0.181 \\
\hline $\mathrm{TP}$ & 0.426 & 0.001 & 0.000 & 0.000 \\
\hline $\mathrm{R}_{\mathrm{CN}}$ & 0.355 & 0.26 & 0.003 & 0.540 \\
\hline $\mathrm{R}_{\mathrm{CP}}$ & 0.289 & 0.001 & 0.000 & 0.672 \\
\hline $\mathrm{R}_{\mathrm{NP}}$ & 0.268 & 0.001 & 0.693 & 0.216 \\
\hline
\end{tabular}

shell fragments deposited on shore by sea winds and waves. This chenier has important academic value for the study about the area's coastline dynamics and paleo environmental and global climate change understanding, as well as maintaining backshore ecological environment stability ${ }^{13}$. It is puzzling, then, that little research has been published about this area to date. Since 2008, a large-area general vegetation investigation in this area has been conducted and found that $T$. chinensis and $Z$. jujube represent two dominant shrub communities most widely distributed here. These two species play a vital role in promoting siltation, improving the ecological environment and maintaining species' diversity. In order to thoroughly understand the soil-plant interactions and elementary cycles in chenier ecosystem, the soil total organic carbon, total nitrogen and total phosphorus contents in the two shrub communities were studied, striving to interpret the patterns of soil elementary composition and stoichiometry. There was little soil nutrient in shrub communities, with average content about 3.73, 0.11 and $0.14 \mathrm{~g} / \mathrm{kg}$ of total organic carbon, total nitrogen and total phosphorus, which were similar to the Tibetan Plateau alpine wetlands, but far below the Sanjiang Plain Wetlands (Table-4). Also, there are significant variance in total organic carbon, total nitrogen and total phosphorus content about 100.80, 90.91 and $50.00 \%$, respectively. The cause of this may be the location of these two plant communities. T. chinensis community was near the high tide line with frequent sea wave erosion, bare ground and surface soil organic matter lack, while Z. jujube was located leeward of the chenier, more litter could accumu-

ABLE-2

OS IN CHENIER IN YELLOW RIVER DELTA

$\begin{array}{cccc}\mathrm{R}_{\mathrm{CN}} & \mathrm{R}_{\mathrm{CP}} & \mathrm{R}_{\mathrm{NP}} & \mathrm{R}_{\mathrm{CNP}} \\ 58.15 \pm 36.19^{\mathrm{ns}} & 38.21 \pm 20.09^{*} & 0.88 \pm 0.55^{*} & 38.21: 0.88: 1 \\ 49.30 \pm 36.63 & 86.58 \pm 44.69 & 2.60 \pm 2.25 & 86.58: 2.6: 1 \\ 53.73 \pm 36.58 & 62.39 \pm 42.19 & 1.74 \pm 1.85 & 62.39: 1.74: 1\end{array}$

late than that in $T$. chinensis community. $\mathrm{P}$ is often considered the main limiting factor in wetland ecosystems with rapid $\mathrm{P}$ leaching by wave erosion ${ }^{14}$. Total phosphorus content in chenier soil was far lower than that in typical seasonal flooding wetland of the Yellow river delta ${ }^{15}$. This lower P content may be caused by weak soil phosphorus adsorption owing to coarser soil and less clay composition in soil ${ }^{16}$. So that, phosphorus deficiency may be an important factor restricted plants growth in the area.

Since the "Redfield ratio" was proposed in 1958, many studies have confirmed the stable Redfield ratio characteristics of terrestrial and marine organisms ${ }^{17,18}$. Some authors have suggested that, as raw source and released pool of elements to plants, the soil system may also manifest a consistent $R_{\mathrm{CNP}}$ ratio over time ${ }^{8,12}$. Compared to the global and regional scales, larger $\mathrm{R}_{\mathrm{CN}}$ was found in chenier shrub soils in Yellow river delta $\left(R_{C N}=53.73\right)$, which might relate to the soil matrix with most shell residues, large $\mathrm{N}$ consumed by microbial decomposition and quickly absorption by plants after release (Table-4). However, large $\mathrm{R}_{\mathrm{CN}}$ might manifest initial stages of soil nitrogen mineralization. The microbial assimilation would exceed mineralization, which may make the plant nitrogen deficiency phenomenon particularly serious ${ }^{19}$. Thus, it could be speculated that the plant in this area may be limited by soil $\mathrm{N}$ element. In addition, $\mathrm{R}_{\mathrm{CP}}$ and $\mathrm{R}_{\mathrm{NP}}$ of shrub soil in chenier wetland in Yellow river delta was far below the level of regional and the global scale (62.39 and 1.74, respectively). The cause may be less organic carbon distribution and low continuous flooding frequency leading to less soil $\mathrm{P}$ leaching and relatively high holding ${ }^{20}$ and what more, study scale may also be an important cause $^{21}$.

Coastal wetland is an ecological transition zone with many environmental factors intense acting and, the soil is a natural complex caused by parent material, topography, biology, climate, time and other factors, so the soil chemical patterns influenced by various factors ${ }^{5}$. In this paper, according to multivariate linear regression, plant community type and soil moisture affected total organic carbon, total nitrogen, total phosphorus content and stoichiometric ratio significantly, however, the impact of soil depth and water table on soil CNP stoichiometry

\begin{tabular}{|c|c|c|c|c|c|c|c|c|}
\hline \multicolumn{9}{|c|}{$\begin{array}{l}\text { TABLE-4 } \\
\text { IN DIFFERE }\end{array}$} \\
\hline Site & Soil depth and type & TOC & $\mathrm{TN}$ & $\mathrm{TP}$ & $\mathrm{R}_{\mathrm{CN}}$ & $\mathrm{R}_{\mathrm{CP}}$ & $\mathrm{R}_{\mathrm{NP}}$ & Cited reference \\
\hline Alpine wetland & $0-30 \mathrm{~cm}$ & 3.6 & 0.2 & 1.0 & 17.5 & 9.3 & 0.53 & 22 \\
\hline \multirow[t]{3}{*}{ Sanjiang plain } & $0-20 \mathrm{~cm}$ & 203.5 & 20.2 & 1.4 & 11.8 & 530 & 45 & 23 \\
\hline & D. angustifolia & - & - & - & 13.0 & 90.5 & 6.1 & 5 \\
\hline & C. lasiocarpa & - & - & - & 13.9 & 467.5 & 25.7 & \\
\hline $\begin{array}{l}\text { Typical seasonal flooding wetland } \\
\text { of the Yellow river delta }\end{array}$ & $0-10 \mathrm{~cm}$ & - & - & 0.66 & - & - & - & 15 \\
\hline China soil & $0-10 \mathrm{~cm}$ & - & - & - & 14.4 & 136 & 9.3 & 12 \\
\hline World scale & $0-10 \mathrm{~cm}$ & - & - & - & 14.3 & 186 & 13 & 8 \\
\hline
\end{tabular}


were not. The community types showed changes of distance from the sea, waves (or wind) erosion, soil particle composition, altitude, species' composition and properties, organic matter presence or absence, water holding and element releasing patterns. The content of soil total organic carbon, total nitrogen and total phosphorus in Z. jujube community were higher than that in $T$. chinensis community, so that there was significant difference among $\mathrm{R}_{\mathrm{CP}}$ and $\mathrm{R}_{\mathrm{NP}}$ (Table-2). Nevertheless, no significant difference was found in $\mathrm{R}_{\mathrm{CN}}$ in two communities that implied that there maybe stable soil ratio of $R_{C N}$ in this area. Further research is needed to determine whether this indicated the relationships and processes during carbon and nitrogen cycling in shell detritus soil matrix in Coast wetlands.

\section{ACKNOWLEDGEMENTS}

This work was supported by the Eleventh and Twelfth Five-year Plan for Supporting Science and Technology of China (Nos. 2010BAC68B01 and 2011BAC02B01-05), the National Science of Foundation of China(Nos. 31100468 and 41201023), Natural Science Foundation of Shandong Province (No. ZR2013CL001) and Project of Shandong Province Development Program (No. J13LE57).

\section{REFERENCES}

1. J.J. Elser, W.F. Fagan, R.F. Denno, D.R. Dobberfuhl, A. Folarin, A. Huberty, S. Interlandi, S.S. Kilham, E. McCauley, K.L. Schulz, E.H. Siemann and R.W. Sterner, Nature, 408, 578 (2000).

2. J.J. Elser, D.R. Dobberfuhl, N.A. MacKay and J.H. Schampel, Bioscience, 46, 674 (1996).
3. A.F. Michaels, Science, 300, 906 (2003).

4. A. Redfield, Am. Sci., 46, 205 (1958).

5. Z.S. Zhang, X.G. Lu, X.L. Song, Y. Guo and Z.S. Xue, J. Soils Sediments, 12, 1309 (2012).

6. E.N. Bui and B.L. Henderson, Plant Soil, 373, 553 (2013).

7. Q.H. Chu, G.X. Pan, D.Y. Li, H.P. Shi, X.H. Zhang, Acta Pedol. Sin., 44, 1083 (2007).

8. C.C. Cleveland and D. Liptzin, Biogeochemistry, 85, 235 (2007).

9. J.M. Stribling and J.C. Cornwell, Wetlands, 21, 629 (2001).

10. M.B.K. Prasad, Environ. Earth. Sci., 67, 293 (2012).

11. C. Bradshaw, U. Kautsky and L. Kumblad, Ecosystems, 15, 591 (2012).

12. H.Q. Tian, G.S. Chen, C. Zhang, J.M. Melillo and C.A.S. Hall, Biogeochemistry, 98, 139 (2010).

13. H. Wang and M. Van Strydonck, Quaternary Res., 47, 192 (1997).

14. Z.S. Zhang, X.L. Song, X.G. Lu and Z.S. Xue, J. Soil. Sediments, 13, 1043 (2013).

15. X. Ye, J. Bai, Q. Lu, Q. Zhao and J. Wang, Environ. Earth Sci., 71, 4811 (2014).

16. Y. Li, R. Li and Y. Shang, Acta Sedimentol. Sin., 18, 46 (2000).

17. R.W. Sterner and J.J. Elser, Ecological Stoichiometry:The Biology of Elements from Molecules to Biosphere, Princeton University Press, Princeton, pp. 110-115 (2002).

18. P.M. Glibert, Curr. Opi. Env. Sust., 4, 1 (2012).

19. S.M. Moseman-Valtierra, K. Armaiz-Nolla and L.A. Levin, Ecol. Appl., 20, 1556 (2009).

20. T.J. Zhang, Y.W. Wang, X.G. Wang, Q.Z. Wang and J.G. Han, Soil Till. Res., 105, 143 (2009).

21. Y. Li, J.S. Wu, S.L. Liu, J.L. Shen, D.Y. Huang, Y.R. Su, W.X. Wei and J.K. Syers, Global Biogeochem. Cycles, 26, GB4002 (2012).

22. J. Bai, H. Ouyang, R. Xiao, J. Gao, H. Gao, B. Cui, L. Huang, Aus. J. Soil. Res., 48, 730 (2010).

23. J. Yang, J. Liu, X. Hu, X. Li, Y. Wang and H. Li, Acta Ecol. Sin., 33,332 (2013). 